\title{
Effects of inoculation with Azospirillum brasilense on photosynthetic enzyme activities and grain yield in maize
}

\author{
I Stancheva ${ }^{1}$, I Dimitrov ${ }^{1}, \mathrm{~N}$ Kaloyanova ${ }^{1}$, A Dimitrova $^{1}$, M Angelov $^{2}$ \\ ${ }^{1} N$ Poushkarov Institute of Soil Science and Agroecology, Shosses Bankja-7, 1080 Sofia; \\ ${ }^{2} \mathrm{M}$ Popov Institute of Plant Physiology, Bulgarian Academy of Science, Sofia, Bulgaria
}

(Received 12 April 1991; accepted 16 January 1992)

\begin{abstract}
Summary - The influence of the inoculation of maize seeds with Azospirillum brasilense strain 1774 on accumulation of dry biomass, phosphoenolpyruvate and ribulose-1,5-bisphosphate carboxylases, nitrate-reductase activity and nitrogen fixing activity was best expressed at a nitrogen dose of $100 \mathrm{~kg} \mathrm{Nha}^{-1}$. The inoculated plants showed a high intensity of dry biomass accumulation at the subsequent phenophases of maize development. The grain yield was similar in the noninoculated and inoculated plants with nitrogen fertilization treatment of 200 and $100 \mathrm{~kg} \mathrm{~N} \mathrm{ha}^{-1}$.
\end{abstract}

Zea mays $(L)=$ maize Azospirillum brasilense/ nitrogenase / phosphoenolpyruvate carboxylase / ribulose-1,5-bisphosphate carboxylase

Résumé - Effets d'une inoculation de Azospirillum brasiliense sur l'activité des enzymes photosynthétiques et le rendement en grain du maïs. L'Influence de l'inoculation du maïs avec la souche 1774 d'Azospirillum brasilense sur l'accumulation de biomasse sèche, les activités phosphoénolpyruvate, ribulosediphosphate carboxylases, nitrate-réductase et l'activité fixatrice d'azote s'exprime mieux à une dose moyenne de fertilisation azotée du maïs. Les plantes inoculées ont montré une vitesse importante d'accumulation de biomasse sèche, dans les phases plus tardives du développement du maïs. Le rendement en grain était le même chez les plantes non-inoculées et inoculées respectivement à 200 et $100 \mathrm{~kg} \cdot \mathrm{ha}^{-1} \mathrm{~d}^{\prime} \mathrm{a}$ zote.

Zea mays $(L)=$ maïs $/$ Azospirillum brasilense $/$ nitrogenase phosphoenolpyruvate carboxylase $/$ ribulosediphosphate carboxylase

\section{INTRODUCTION}

Inoculation of plants with Azospirillum brasilense can result in a significant change in various plant growth parameters, which may affect crop yield. Visible changes have been observed in total plant dry weight, in the amount of nitrogen in shoots and grains and in the grain weight (O'Hara et al, 1981; Albrecht et al, 1983; Bashan and Levanony, 1990).

The effects of inoculation with Azospirillum bacteria on total yield increase in field grown plants have been found to generally range from 10-30\% (O'Hara et al, 1981; Pal and Malik, 1981); nevertheless, the nitrogen fixation by associative bacteria in a temperate climate seems to be negligible (Boddey et al, 1986).

Okon (1985) evaluated the success of Azospirillum inoculation and concluded that positive effects on yield were obtained in approximately $65 \%$ of all field experiments. However, negative results or no effect of inoculation on grain yield have been reported (Albrecht et al, 1983; Smith et al, 1984; Harris et al, 1989).

The highest yield increases were obtained when the levels of nitrogen fertilization were 
suboptimal for normal plant development (Baldani and Döbereiner, 1981; O'Hara et al, 1987). The normal development of maize after inoculation was obtained at a nitrogen level which was $10-20 \%$ of the optimum level (Stephen et al, 1982).

The aim of our investigation was to determine the influence of the inoculation of maize seeds with Azospirillum brasilense on photosynthetic activity and grain yield at different nitrogen doses.

\section{Materials and Methods}

\section{Organisms and growth conditions}

The investigations were made on the basis of 2 years of field experiments including 3 levels of nitrogen fertilization $\left(0,100,200 \mathrm{~kg} \mathrm{~N} \mathrm{ha}^{-1}\right) 55000$ plants per ha and a nondeficient water regime. The maize plants, Zea mays (L) hybrid $\mathrm{H} 708$, were grown on leached cinnamonic forest soil whose organic matter content was $1.7-1.0 \%$ and $\mathrm{pH}$ 6.6.

A randomized block design with 4 replicates was used to test inoculation with Azospirillum. Each plot was $64 \mathrm{~m}^{2}$ in area and consisted of 12 rows. The seeds were inoculated with Azospirillum brasilenze strain 1774 (UQM, 13 collection) donated by $\mathrm{Dr} \mathrm{LI}$ Sly from the University of Queensland, Australia. Azospirillum brasilense bacteria were grown on semi-liquid malate medium (Albrecht and Okon, 1980). Inoculation was performed before sowing with inoculum containing $10^{8}$ colony-forming units $\mathrm{ml}^{-1}$ and $400 \mathrm{ml}$ per each $\mathrm{kg}$ of seeds.

Microbial tests were performed in root samples taken from 3 plants chosen at random from each plot. Isolation, identification and counting of Azospirillum were performed according to Okon et al (1977).

\section{Enzyme assay}

Ribulose-1,5-bisphosphate carboxylase RuBPC (E.C.4.1.1.31) activity was measured according to the method of Angelov (Angelov et al, 1987). The leaf tissue $(0.5 \mathrm{~g}$ fresh matter) was homogenized at $4{ }^{\circ} \mathrm{C}$ with $5 \mathrm{~cm}^{3}$ buffer containing (mM) : HEPES$\mathrm{KOH}(\mathrm{pH}=8.0)$, 50; sorbitol, 330; $\mathrm{KNO}_{3}, 2$; EDTA, 2; $\mathrm{MgCl}_{2,1} ; \mathrm{K}_{2} \mathrm{HPO}_{4}, 0.5 ; \mathrm{NaCl}, 20$; isoascorbate (sodium salt), 2; Polyclar AT $(10 \% \mathrm{~m} / \mathrm{v})$ was added to each sample. The homogenate was passed through 4 layers of cheesecloth and the filtrate was centrifuged at $10000 \mathrm{~g}$ for $10 \mathrm{~min}$ at $0^{\circ} \mathrm{C}$. The reaction mixture $\left(1 \mathrm{~cm}^{3}\right)$ for $\mathrm{RuBPC}$ contained
(mM) : HEPES-KOH $(\mathrm{pH}=8.0), 20 ; \mathrm{MgCl}_{2}, 20$; DTT, 10; $\mathrm{NaHCO}_{3}, 20 ; \mathrm{NaH}^{14} \mathrm{CO}_{3}, 100 \mathrm{~mm}^{3}$ (specific activity $1.67 \mathrm{MBq} \mu \mathrm{mol}^{-1}$ ) and $0.4 \mathrm{~cm}^{3}$ homogenate. The RUBPC was activated at $25^{\circ} \mathrm{C}$ for 10 min and the enzyme reaction was stopped with $3 \mathrm{~N} \mathrm{HCl}$.

PEPC activity was determined in the reaction mixture $\left(1 \mathrm{~cm}^{3}\right)$ containing $(\mathrm{mM})$ : HEPE-KOH, 20; $\mathrm{MgCl}_{2}, 10 ; \mathrm{DTT}, 10 ; \mathrm{NaDH}$ (disodium salt), 0.4 ; $\mathrm{NaHCO}_{3}, 20 ; \mathrm{NaH}^{14} \mathrm{CO}_{3}, 100 \mathrm{~mm}^{3}$ and $0.4 \mathrm{~cm}^{3}$ homogenate.

The PEPC was activated at $30^{\circ} \mathrm{C}$ for $5 \mathrm{~min}$ and the enzyme reaction started by addition of PEP (Merck). The radiometric activity of carboxylases was determined in a liquid scintillator counter.

Nitrogenase activity was determined by the $\mathrm{C}_{2} \mathrm{H}_{2}$-reduction method on the excised roots (Döbereiner, 1978). The roots were placed under polyethylene bags and exposed to acetyleneenriched air (10\% acetylene) for $24 \mathrm{~h}$. The gas samples were injected into a gas chromatograph fitted with a flame ionisation detector. The gas peaks were analysed and the amount of ethylene produced was calibrated against a commercially prepared ethylene standard of known ethylene concentration.

Nitrate-reductase activity (E.C.1.6.6.1) was measured according to Klepper et al (1971). Ten plants per variant were taken for dry matter determination. The experimental data were subjected to standard statistical procedure.

\section{Results and Discussion}

The data of biomass accumulation during the different phenophases are shown in figure 1. An even accumulation of dry biomass was observed till the milk ripeness phase in non-fertilized variants in the non-inoculated as well as in the inoculated plants. In the non-inoculated fertilized variants, plants acquired a higher forming rate of dry biomass between the tasseling and milk ripeness phases. In contrast to non-inoculated plants, inoculated plants showed higher forming rate of dry biomass after the milk ripeness phase. This trend was observed at the 3 levels of nitrogen fertilization, but was most significant at $100 \mathrm{~kg} \mathrm{~N} \mathrm{ha}^{-1}$. The growth in dry biomass of the maize inoculated with Azospirillum at the subsequent phenophases has been reported by other authors (Pidello, 1981; Okon, 1982; Barber et al, 1986).

The dry biomass increased with nitrogen doses independently of the inoculation (fig 1). 
On the other hand, the influence of inoculation on dry biomass accumulation was best expressed at $100 \mathrm{~kg} \mathrm{~N} \mathrm{ha}^{-1}$, since significant differences were observed in total plant dry weight (fig 1). There was no effect of inoculation on accumulation of dry biomass in variants without nitrogen. The investigation of the influence of inoculation on yield production has very important practical implications. The statistically reliable differences in yield production are shown under the influence of the fertilizing factor only (tablel). The influence of inoculation and the interaction between both factors on yield production has not been proven mathematically.

By analyzing our results it is clear that practically equal results are obtained in the variants of $200 \mathrm{~kg} \mathrm{~N}^{-1}$ nitrogen noninoculated and $100 \mathrm{~kg} \mathrm{ha}^{-1}$ nitrogen inoculated with Azospirillum brasilense. The results indicate that the optimal nitrogen dose for maize grown under these soil-climatic conditions while applying inoculum of $A$ brasilense is close to $100 \mathrm{~N} \mathrm{~kg} \mathrm{ha}^{-1}$.

The grain yield is formed at the determined parameters of the maize stand: maximum leaf area index $(\mathrm{LAl}), \mathrm{m}^{2} \cdot \mathrm{m}^{-2}$; average net photosynthetic productivity $(\mathrm{Pn})$, gram dry weight per $\mathrm{m}^{2}$ leaf area per day; maximum height of the plants, $m$.

In the variants with $200 \mathrm{~kg} \mathrm{~N}^{-1}$ without $A$ brasilense, maximum leaf area index generally ranged from $3.5-4.8$, average net photosynthetic productivity from $6.27-7.70$ and maximum height of the plants from 2.68-2.98.
In the inoculated variants with $100 \mathrm{~kg} \mathrm{~N}^{-1}$ maximum leaf area index changed from 3.3 to $4.4, \mathrm{Pn}$ from 6.26 to 7.17 and the plant height from 2.74 to 2.75 . The values of these parameters in the 2 variants considered do not differ significantly.

Nitrogen fixing activity was detected in all variants at grain filling phase (table II). According to some authors (Xavier et al, 1982; Rao and Venkateswarlu, 1985), root extracts from plants collected at this growth stage stimulated Azospirillum growth to a great extent. The high intensity of dry biomass accumulation in inoculated plants after the milk ripeness phase (fig 1 ) is possibly due to this specific plant-bacteria interaction. The nitrogenase activity in the inoculated plants without nitrogen and $100 \mathrm{~kg} \mathrm{~N} \mathrm{ha}^{-1}$ variants was higher than in those with $200 \mathrm{~kg} \mathrm{~N} \mathrm{ha}^{-1}$. In the variants at 0 and $100 \mathrm{~kg} \mathrm{~N} \mathrm{ha}^{-1}$ the nitrogenase activity was increased 2-3-fold in comparison with non-inoculated plants. From an analysis of these results, it is not clear in which phenophase of maize development the nitrogen fixing activity is higher. The high values of nitrogenase activity in the non-inoculated variants are probably due to the presence of active native strains of Azospirillum. The number of Azospirillum bacteria in the rhizosphere of non-inoculated plants is high. Our results (table II) showed that there is no correspondence between the values of nitrogen fixing activity and the number of Azospirillum bacteria in the investigated variants. There are cases when the number of Azospirillum bacteria is higher in the non-inoculated va-
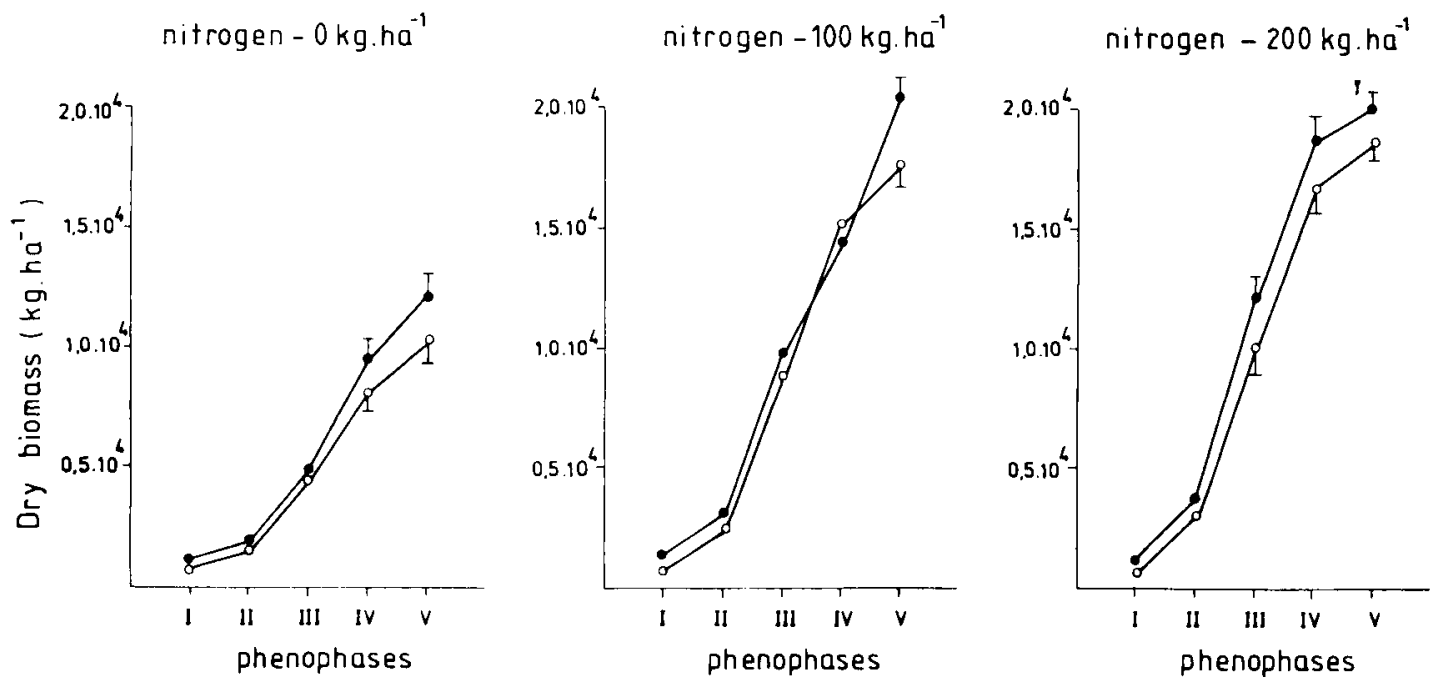

Fig 1. Effects of Azospirillum brasilense inoculation on dry matter accumulation in maize. Results represent means of 2 experiments $(1988,1989)$. Vertical bars indicate least significant difference at $P=0.05$. Phenophases : I, 7-8th leaf; II, 10-11th leaf; III, tasseling; IV, milk ripeness; V, wax ripeness; $\bullet$, inoculated; $O$, non-inoculated. 
riants. Analogous trends have been observed in association with the roots of several $\mathrm{C}_{4}$ plants by other authors (Alexander and Zuberer, 1988; Michiels et al, 1989). No correlation was found between nitrogen fixing activity and the grain yield.

The plants inoculated with $A$ brasilense usually show high enzyme activity. The influence of inoculation on the main photosynthetic enzymes depends on maize development (fig 2). The highest enzyme activity was found in the period of straightened growth, ie the 10-11th leaf. The activity of PEPC and RuBPC-ase enzymes at each phenophase in inoculated variants was significantly higher at $100 \mathrm{~kg} \mathrm{~N} \mathrm{ha}^{-1}$ (fig 2).
Nitrate-reductase activity increased with nitrogen fertilization (fig 2). In the noninoculated variants the increase was higher within the range of $100-200 \mathrm{~kg} \mathrm{~N} \mathrm{ha}^{-1}$, while in the inoculated variants, it was within the range of $0-100 \mathrm{~kg} \mathrm{~N} \mathrm{ha}^{-1}$. Therefore the effect of inoculation with $A$ brasilense on the physiological activity of the plants is associated with an increase in nitrate-reductase activity at low levels of nitrogen fertilization. This trend is best expressed at $100 \mathrm{~kg} \mathrm{~N} \mathrm{ha}^{-1}$ at the 3 phenophases investigated. A possible explanation for the high values of nitrate-reductase activity in the inoculated variants at a nitrogen level of $100 \mathrm{~kg} \mathrm{~N} \mathrm{ha}^{-1}$ is an increase in the effectiveness of the nitrogen fertilizer due to the

Table I. Grain yield, $\mathrm{kg} \mathrm{ha}^{-1}$ in function of inoculation at different nitrogen doses.

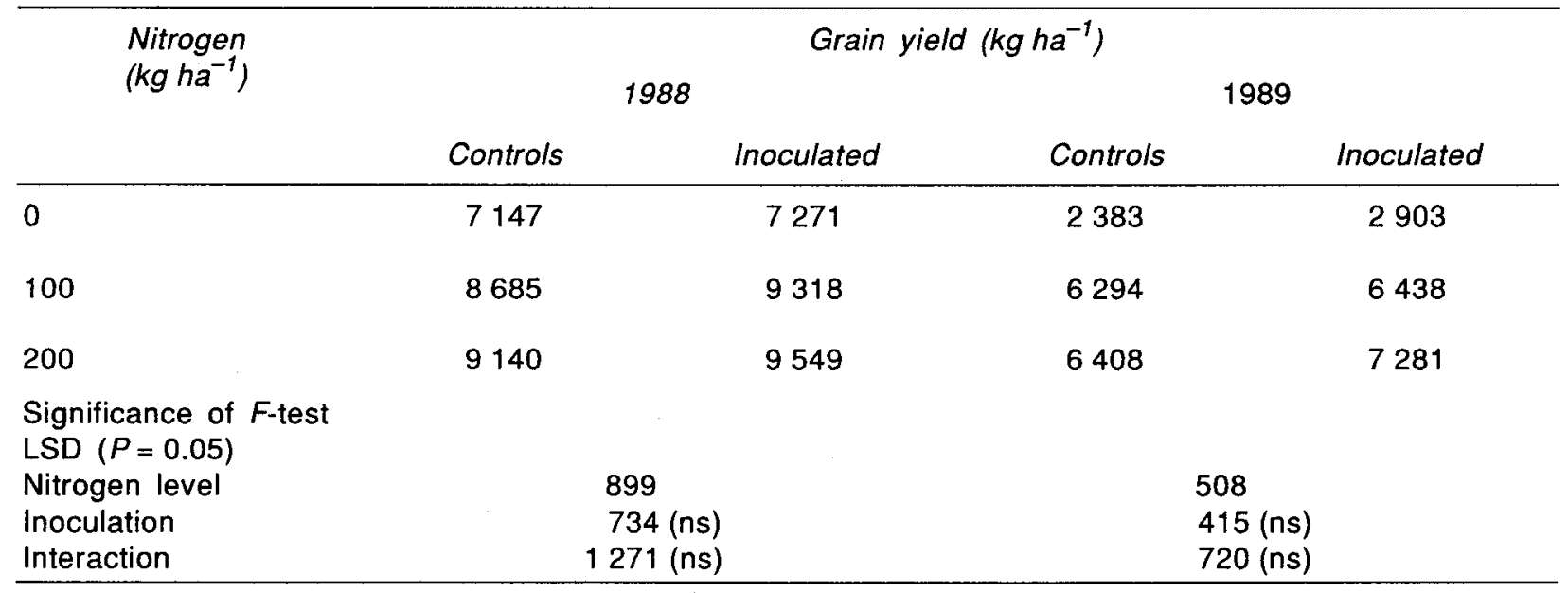

ns : Differences are non-significant.

Table II. Nitrogenase activity, $\mu \mathrm{mol} \mathrm{C}_{2} \mathrm{H}_{2} \mathrm{~h}^{-1}$ plant $^{-1} \cdot 10^{3}$ (a) and numbers of Azospirillum bacteria $\cdot 10^{6}$ per gram soil (b).

\begin{tabular}{|c|c|c|c|c|c|c|c|c|c|}
\hline \multirow{3}{*}{$\begin{array}{l}\text { Nitrogen } \\
\left(\mathrm{kg} \mathrm{ha}^{-1}\right)\end{array}$} & \multirow[t]{3}{*}{ Treatment } & \multicolumn{4}{|c|}{1988} & \multicolumn{4}{|c|}{1989} \\
\hline & & \multicolumn{2}{|c|}{ Grain filling } & \multicolumn{2}{|c|}{ Milk ripeness } & \multicolumn{2}{|c|}{ Grain filling } & \multicolumn{2}{|c|}{ Milk ripeness } \\
\hline & & $a$ & $b$ & $a$ & $b$ & $a$ & $b$ & $a$ & $b$ \\
\hline 0 & $\begin{array}{l}\text { Inoculated } \\
\text { Non-inoculated } \\
n^{* \star}\end{array}$ & $\begin{array}{c}951^{\star a} \\
396^{b} \\
3\end{array}$ & $\begin{array}{l}1.3^{\mathrm{a}} \\
0.2^{\mathrm{b}} \\
3\end{array}$ & $\begin{array}{c}1379^{\mathrm{a}} \\
302^{\mathrm{b}} \\
3\end{array}$ & $\begin{array}{c}1.5^{\mathrm{a}} \\
0.2^{\mathrm{b}} \\
3\end{array}$ & $\begin{array}{c}177^{\mathrm{a}} \\
162^{\mathrm{a}} \\
3\end{array}$ & $\begin{array}{c}3.8^{\mathrm{a}} \\
3.3^{\mathrm{a}} \\
3\end{array}$ & $\begin{array}{c}220^{\mathrm{a}} \\
63^{\mathrm{b}} \\
2\end{array}$ & $\begin{array}{r}2.9^{\mathrm{a}} \\
1.2^{\mathrm{b}} \\
3\end{array}$ \\
\hline 100 & $\begin{array}{l}\text { Inoculated } \\
\text { Non-inoculated } \\
n\end{array}$ & $\begin{array}{c}1127^{\mathrm{a}} \\
558^{\mathrm{b}} \\
2\end{array}$ & $\begin{array}{c}1.0^{\mathrm{a}} \\
1.0^{\mathrm{a}} \\
3\end{array}$ & $\begin{array}{c}690^{\mathrm{a}} \\
151^{\mathrm{b}} \\
3\end{array}$ & $\begin{array}{r}1.0^{\mathrm{a}} \\
0.6^{\mathrm{b}} \\
3\end{array}$ & $\begin{array}{c}164^{\mathrm{a}} \\
81^{\mathrm{b}} \\
3\end{array}$ & $\begin{array}{r}4.0^{\mathrm{a}} \\
3.2^{\mathrm{b}} \\
3\end{array}$ & $\begin{array}{c}540^{\mathrm{a}} \\
144^{\mathrm{b}} \\
3\end{array}$ & $\begin{array}{r}3.0^{\mathrm{a}} \\
1.7^{\mathrm{b}} \\
3\end{array}$ \\
\hline 200 & $\begin{array}{l}\text { Inoculated } \\
\text { Non-inoculated } \\
n\end{array}$ & $\begin{array}{r}810^{a} \\
1029^{b} \\
3\end{array}$ & $\begin{array}{c}0.9^{\mathrm{a}} \\
1.3^{\mathrm{b}} \\
3\end{array}$ & $\begin{array}{c}828^{a} \\
776^{a} \\
3\end{array}$ & $\begin{array}{c}1.0^{\mathrm{a}} \\
0.9^{\mathrm{a}} \\
3\end{array}$ & $\begin{array}{c}101^{\mathrm{a}} \\
129^{\mathrm{a}} \\
3\end{array}$ & $\begin{array}{c}4.6^{\mathrm{a}} \\
4.7^{\mathrm{a}} \\
3\end{array}$ & $\begin{array}{c}139^{\mathrm{a}} \\
73^{\mathrm{b}} \\
3\end{array}$ & $\begin{array}{r}7.6^{\mathrm{a}} \\
2.2^{\mathrm{b}} \\
3\end{array}$ \\
\hline
\end{tabular}

* Numbers in each column followed by different letters differ significantly at $P=0.05 .{ }^{* *} n$ : number of replicates. 

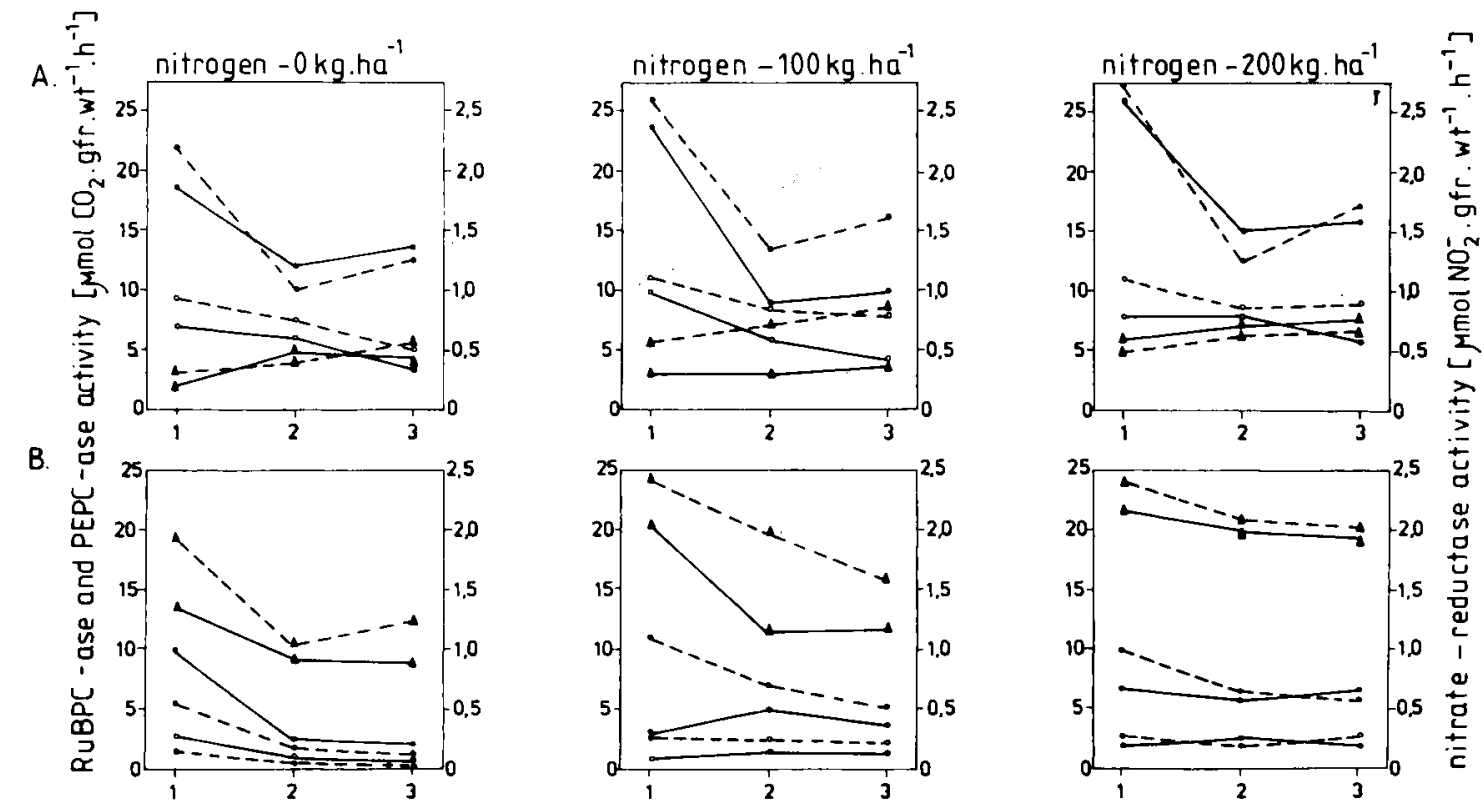

Fig 2. Effects of Azospirillum brasilense inoculation on RUBPC-ase, PEPC-ase and nitrate-reductase activities in maize in $1988(A)$ and $1989(B)$. 1, 10-11th leaf; 2 , grain filling; 3 , milk ripeness; $O$, RuBPC-ase; $\bullet, P E P C$-ase; $\triangle$, nitrate-reductase; - non-inoculated; ----, inoculated.

activity of Azospirillum bacteria (Pereira et al, 1978; Baldani and Döbereiner, 1981; Kostov et al, 1990). Some authors (Pereira et al, 1978) also found that there was a simultaneous enrichment of biological nitrogen and nitrate assimilation at low nitrogen doses in maize. In conclusion, the application of $A$ brasilense strain 1774 increased the nitrogen fixing activity in the roots mainly at nitrogen level 0 and $100 \mathrm{~kg} \mathrm{ha}^{-1}$.

\section{CONCLUSION}

The grain yield was nearly equal in the noninoculated variants at $200 \mathrm{~kg} \mathrm{~N}^{-1}$ and in the inoculated variants at $100 \mathrm{~kg} \mathrm{~N} \mathrm{ha}^{-1}$. The influence of inoculation on accumulation of dry biomass was best expressed at $100 \mathrm{~kg} \mathrm{~N} \mathrm{ha}^{-1}$ and the inoculated plants showed a high biomass growth intensity at the later phenophases of maize development.

The effect of inoculation on enzyme activity in maize was most significant at $100 \mathrm{~kg} \mathrm{~N} \mathrm{ha}^{-1}$. This influence is probably due to nitrogen fixing bacterial secretion of plant hormones which leads to root system proliferation and plant nitrogen metabolism stimulation. However, this needs to be experimentally confirmed in future investigations.

\section{ACKNOWLEDGMENTS}

This work was supported by a grant from the Agricultural Academy and the Academy of Sciences of Bulgaria.

\section{REFERENCES}

Albrecht SL, Okon Y (1980) Cultures of Azospirillum. Methods Enzymol 69, 740-749

Albrecht SL, Gaskins MH, Milam JR, Schank SC, Smith RL (1983) Ecological factors affecting survival and activity of Azospirillum in the rhizosphere. In: Azospirillum II: Genetics, Physiology, Ecology (Klingmüller W, ed) Birkhäuser, Basel, 138-148

Alexander DL, Zuberer DA (1988) Impact of soil environmental factors on rates of $\mathrm{N}_{2}$-fixation associated with roots of intact maize and sorghum plants. Plant Soil 110, 303-315

Angelov M, Stanev VP, Dimitrov IG, Stoyanov PA (1987) Activity of carboxylating enzymes in maize leaves on the vertical profile in a highly productive crop. Physiol Rasteniata (Sofia) 13(4), 3-7

Baldani VD, Döbereiner J (1981) Host plant specificity in the infection of maize, wheat and rice with Azospirillum sp. In: Associative $\mathrm{N}_{2}$-Fixation.l (Vose P, Ruschel A, eds) CRC Press Inc, Boca Raton, FL, 132-136 
Barber LE, Tjepkema JD, Russel SA, Evans HY (1986) Acetylene reduction associated with corn inoculated with Spirillum. App/ Environ Microbiol 1, 108-113

Bashan Y, Levanony H (1990) Current status of Azospirillum inoculation technology: Azospirillum as a challenge for agriculture. Can J Microbiol 36, 109-121

Boddey RM, Baldani VLD, Baldani Jl, Döbereiner $J(1986)$ Effect of inoculation of Azospirillum on the nitrogen assimilation of field-grown wheat. Plant Soil 95, 109-121

Döbereiner $\mathrm{J}$ (1978) Nitrogen fixation in grass-bacteria associatione in the tropics. In: Isotopes in Biological Dinitrogen Fixation. Int Atomic Energy Agency, Vienna, 51-69

Harris JM, Lucas JA, Davay MR, Lethbridge G, Powell KA (1989) Establishment of Azospirillum inoculation in the rhizosphere of winter wheat. Soil Biol Biochem 21, 59-64

Klepper LA, Flesher DE, Hageman RH (1971) Generation of reduced nicotinamide adenine dinucleotide for nitrate reduction in green leaves. Plant Physiol 48, 580-590

Kostov O, Dimitrowa A, Kalojanova N (1990) Associative $\mathrm{N}_{2}$-fixation. In: Soils of Bulgaria. II (Stoyanov D, Shopsky N, eds) (in press)

Michiels K, Vanderleyden J, Van Cool A (1989) Azospirillum-plant root associations : a review. Biol Fertil Soils 8, 356-368

O'Hara GW, Davey MR, Lucas JA (1981) Effect of inoculation of Zea mays with Azospirillum brasilense strains under temperate conditions. Can $J$ Microbiol 27, 871-877

O'Hara GW, Davey MR, Lucas JA (1987) Effects of nitrogen on the yield response of Pennisetum americanum, Triticum sativum and Zea mays to inoculation with $A$ brasilense under temperate conditions. Biol Fertil Soils 4, 57-72

Okon Y, Albrecht SL, Burris RH (1977) Methods for growing Spirillum lipoferum and for counting it in pure culture and in association with plants. Appl Environ Microbiol 33, 85-88

Okon $Y$ (1982) Azospirillum: Physiology, properties, mode of association with roots and its application for the benefit of cereal and forage grass crops. Isr $J$ Bot $31,214-220$

Okon Y (1985) Azospirillum as a potential inoculant for agriculture. Trends Biotechnol 3, 223-228

Pal UR, Malik HS (1981) Contribution of Azospirillum brasilense to the nitrogen needs of grain sorghum in humid subtropics. In: Associative $\mathrm{N}_{2}$-Fixation. I (Vose P, Ruschel A, eds) CRC Press Inc, Boca Raton, FL, 152-163

Pereira PA, Von Bülov JF, Neyra CA (1978) Atividade da nitrogenase, nitrato-reductase e acumulacāo de nitrogênio em mulho braguítico Zea mays L (cv, Piranão) em dois níveis de adubacão nitrogenda. Rev Bras Cien Solo 2, 28-33

Pidello A (1981) Influence of combined mineral nitrogen on rhizosphere fixation of nitrogen by maize. In: Associative $\mathrm{N}_{2}$ Fixation. I (Vose $\mathrm{P}$, Ruschel A, eds) CRC Press Inc, Boca Raton, FL, 192-199

Rao AV, Venkateswarlu B (1985) Most probable numbers of Azospirillum associated with the roots of inoculated pearl millet. Plant Soil 88 , 153-158

Smith RL, Schank SC, Milam JR, Battensperger AA (1984) Response of Sorghum and Pennisetum species to the $\mathrm{N}_{2}$-fixing bacterium Azospirillum brasilense. Appl Environ Microbiol 47, 13311336

Stephen VE, Anderson MA, Brill VJ (1982) Screening and selection of maize to enhance associative bacterial nitrogen fixation. Plant Physiol 2, 236-241

Xavier DF, Baldani JI, Baldani VD, Döbereiner J (1982) Effect of maize root extract of growth and nitrogenase activity of Azospirillum spp. An Acad Bras Cien 54, 761-768 